\title{
FAKTOR-FAKTOR YANG MENGHAMBAT PROSES DOKUMENTASI KEPERAWATAN
}

\author{
Elisa Claudia Simanjuntak / 181101114 \\ elclaudia02@gmail.com
}

\begin{abstract}
ABSTRAK
Latar Belakang : Dalam melakukan perannya, perawat harus mampu memberikan pelayanan yang bermutu dan sesuai standar. Memberikan asuhan keperawatan sesuai standar dapat dilakukan melalui penerapan proses keperawatan.

Tujuan : Tujuan penulisan kajian ini adalah untuk mengetahui faktor-faktor yang menghambat proses dokumentasi keperawatan.

Metode : Metode yang digunakan dalam kajian ini adalah literature review, yaitu dengan cara menganalisis, mengeksplorasi serta mengkaji bebas jurnal dan buku teks yang membahas tentang dokumentasi keperawatan.

Hasil : Hasil kajian menunjukkan bahwa dalam melakukan dokumentasi keperawatan, ada beberapa faktor yang dapat menghambatnya.

Pembahasan : Dokumentasi adalah catatan yang dikumpulkan secara menyeluruh, mencakup bio-psiko-sosio-spiritual yang komprehensif. Namun, dalam menjalankan dokumentasi tidak selalu baik. Ada beberapa faktor yang dapat menghambat proses dokumentasi.
\end{abstract}

Kata Kunci : Faktor, Dokumentasi, Keperawatan. 


\section{Latar Belakang}

Perawat sebagai salah satu tenaga kesehatan mempunyai peran yang besar untuk kesembuhan pasien.

Dalam melakukan perannya, perawat harus mampu memberikan pelayanan yang bermutu dan sesuai standar. Memberikan asuhan keperawatan sesuai standar dapat dilakukan melalui penerapan proses keperawatan. Proses keperawatan meliputi pengkajian, diagnosis, perencanaan, implementasi, evaluasi, serta dokumentasi.

Pelayanan

keperawatan profesional yang berdasarkan ilmu pengetahuan mempunyai proses keperawatan yaitu suatu asuhan keperawatan sebagai metode ilmiah penyelesaian masalah keperawatan pasien untuk meningkatkan outcome pasien yang harus didokumentasikan (Aziz,2002). Namun, dalam aplikasinya dokumentasi keperawatan tidak selalu berjalan mulus.

\section{Tujuan}

Pengkajian ini dilakukan untuk mengetahui faktor-faktor yang menghambat proses dokumentasi keperawatan.

\section{Metode}

Metode yang digunakan dalam kajian ini adalah literature review, yaitu dengan cara menganalisis, mengeksplorasi serta mengkaji bebas jurnal dan buku teks yang membahas tentang dokumentasi keperawatan. Referensi berupa jurnal dan buku teks yang digunakan adalah sebanyak 14 . Jurnal yang digunakan sebagai referensi dalam tulisan ini diterbitkan dalam kurun waktu 10 tahun terakhir.

\section{Hasil}

Dalam melakukan dokumentasi keperawatan, ada beberapa faktor yang dapat menghambatnya.

\section{Pembahasan}

Dokumentasi keperawatan adalah suatu dokumen yang berisi data yang lengkap, nyata, dan tercatat, bukan hanya tentang kesakitan pasien, tetapi juga jenis/tipe, kualitas, dan kuantitas pelayanan kesehatan dalam memenuhi kebutuhan klien (Fisbach, 1991). Dapat disimpulkan bahwa dokumentasi adalah catatan yang dikumpulkan secara menyeluruh, mencakup bio-psiko-sosiospiritual yang komprehensif. Catatan tersebut nantinya akan digunakan untuk 
pengkajian, diagnosa, perencanaan, tindakan, dan evaluasi.

Dalam menjalankan

dokumentasi tidak selalu baik. Ada halhal yang dapat menghambat proses dokumentasi, antara lain :

1. Tingkat pengetahuan perawat.

Apabila tingkat pengetahuan perawat rendah, pelaksanaan dokumentasi dapat berjalan tidak baik atau bahkan tidak dilakukan sama sekali.

2. Kurangnya pemahaman dasar-dasar dokumentasi keperawatan.

Hal ini bisaterjadi karena latar belakang pendidikan yang berbeda-beda, sehingga tidakadanya keseragaman pelaksanaan dokumentasi keperawatan.

3. Kurangnya kesadaran akan pentingnya dokumentasi keperawatan. Penulisandokumentasi keperawatan tidak mengacu pada standar yang sudahditetapkan, sehingga terkadang tidak lengkap dan akurat.

4. Dokumentasi keperawatan dianggap beban.

Banyaknya lembar format yang harus diisi untuk mencatat data dan intervensi keperawatan pada pasien dianggap beban oleh perawat.

5. Keterbatasan tenaga.

Kurangnya tenaga perawat yang ada dalam suatu tatanan pelayanan kesehatan memungkinkan perawat bekerja hanya berorientasi pada tindakan saja. Karena perawat tidak memiliki cukup waktu untuk menuliskan setiap tindakan yang telah diberikan pada lembar format dokumentasi keperawatan.

6. Ketiadaan pengadaan lembar format dokumentasi keperawatan oleh institusi. Hal ini mungkin menjadi pertimbangan institusi karena akan membutuhkan biaya yang tidak sedikit.

\section{Penutup}

Proses keperawatan tidak selalu berjalan mulus. Salah satunya pada tahap dokumentasi keperawatan. Pelaksanaannya dipengaruhi oleh beberapa faktor yang dapat menghambat. Kualitas perawatan yang akan diberikan kepada pasien bergantung kepada kemampuan perawat melakukan tindakan sesuai dengan standar (mengikuti proses keperawatan).

\section{Referensi}

Ali, H. Z. (2009). Dasar-dasar Dokumentasi Keperawatan. Jakarta: EGC. 
Astar, F. dkk. (2018). Pengaruh Pelayanan Asuhan Keperawatan Terhadap Kepuasan Pasien di Puskesmas Takalala Kabupaten Soppeng. Journal of Management. 1(2): 33-57.

Deswani. (2009). Proses Keperawatan dan Berpikir Kritis. Jakarta: Salemba Medika.

Haryanto. (2008). Konsep Dasar Keperawatan dengan Pemetaan Konsep (Concept Mapping). Jakarta: Salemba Medika.

Kasim, M. \& M. Abdurrouf. (2016). Peningkatan Kualitas Pelayanan dan Pendokumentasian Asuhan Keperawatan Dengan Metode Tim. NurseLine Journal. 1(1): 62-72.

Maryam, Siti, dkk. (2006). Buku Ajar Berpikir Kritis dalam Proses Keperawatan. Jakarta: EGC.

Noorkasiani, dkk. (2015). FaktorFaktor Yang Berhubungan Dengan Kelengkapan Dokumentasi Keperawatan. Jurnal Keperawatan Indonesia. 18(1): 1-8.
Potter \& Perry. (2005). Buku Ajar Fundamental Keperawatan: Konsep, Proses, dan Praktik Edisi 4. Jakarta: EGC.

Rosmalia, D. dkk. (2014). Analisis Sistim Manajemen Dokumentasi Keperawatan pada Poliklinik Gigi Rumah Sakit di Bukittinggi. Jurnal Kesehatan Andalas. 4(3): 967-972.

Simamora, R.H. (2009). Dokumentasi Proses Keperawatan. Jember: Jember University Press.

Simamora, R.H. (2010). Komunikasi dalam Keperawatan. Jember: Jember University Press.

Simamora, R. H. (2008). Peran Manajer dalam Pembinaan Etika Perawat Pelaksana dalam Peningkatan Kualitas Pelayanan Asuhan Keperawatan. Jurnal IKESMA. 4(2).

Sugiyati, S. (2015). Hubungan Pengetahuan Perawat Dalam Dokumentasi Keperawatan Dengan Pelaksanaannya di Rawat Inap RSI Kendal. Jurnal Keperawatan. 8(2): 109125. 
Tarwoto \& Wartonah. (2012).

Kebutuhan Dasar Manusia dan Proses

Keperawatan. Jakarta: Salemba

Medika. 